\title{
MORE ON THE ORIGIN OF THE INDO-EUROPEAN FEMININE GENDER: A REPLY TO LEDO-LEMOS
}

One of the most enduring questions of Indo-European linguistics has been the origin of the feminine gender. Indeed, from the inception of modern historical linguistics through the work of the Neogrammarians (cf. Brugmann 1897), the matter has been debated extensively. Of course, special impetus for such continuing debate was provided by the decipherment of the Hittite texts and the discovery that Hittite lacks the feminine gender category, possessing only an animate (common) and a neuter (inanimate) gender. ${ }^{1}$ It would appear, then, that the origin of the feminine gender is to be ascribed to the relatively recent linguistic past-the period of Indo-European dialectal differentiation. I myself have written extensively about the origin of this grammatical category (cf. Shields 1977, 1979, 1982: 72-84, and 1995), but a more recent hypothesis appears in Femininum Genus: $A$ Study on the Origin of the Indo-European Feminine Grammatical Gender (2003), by Francisco José Ledo-Lemos. ${ }^{2}$ Before presenting the details of his new theory, Ledo-Lemos provides arguments against the cogency of my proposal. In this brief paper I intend to respond to the criticisms of Ledo-Lemos and to point out what I perceive as weaknesses in his hypothesis. I offer my comments not as statements of absolute proof but as statements designed to further the debate on this interesting and significant issue of Indo-European linguistics.

\footnotetext{
*Author's address: PO Box 1002, 1 South George St, Millersville, PA 17551, USA.

Email: KennethKCS48@aol.com

1 The debate about whether or not Hittite ever had the feminine gender also remains lively. Melchert (1994) very recently asserts that there is evidence for a feminine in Anatolian in the form of a "motion suffix" $-i$ - added to common gender nouns in Luvian and perhaps some adjectives in Hittite. However, as Matasović (2004: 39) significantly observes, "a major indication that Anatolian actually never had the third gender comes from typology. It has been observed that, when gender distinctions are lost, their traces are almost always preserved in demonstrative pronouns, if anywhere in the language .... Thus, if there were any traces of the feminine gender in Anatolian, one would expect them to be preserved in the pronominal system, rather than in adjectives and nouns, where their potential functional load would have been minimal."

${ }^{2}$ Still another very recent attempt to explain the origin of the feminine category is contained in Gender in Indo-Eurpean (2004), by Ranko Matasović. Although Matasović does not cite my scholarship, his view of the origin of the feminine (cf. 2004: 173-176) is essentially the one which I have proposed in Shields (1995). Nevertheless, this new book of his demonstrates once again the continued interest of Indo-Europeanists in this topic. Other recent studies of Indo-European gender include Euler (1991), Tichy (1993), Stempel (1994), Melchert (1994), Zielfelder (2001), and Schwink (2004).
} 
Although my views on the origin of the Indo-European feminine gender have evolved over several decades, especially as relevant typological data have become more important in evaluating the validity of reconstructions, I continue to endorse the proposal which appears in Shields (1995). In short, my theory is founded on the typological principle articulated by both Corbett (1991: 310) and Greenberg (1978) that demonstratives play a central role in the rise of gender systems because these forms manifest concord with nouns both as anaphora and as attributive modifiers. Thus, in my opinion, a deictic/demonstrative in ${ }^{*} \bar{a}$, attested widely in traditionally reconstructed feminine demonstratives (e.g., nom. sg. ${ }^{*} s \bar{a}$ : Skt. sấ, Gk. hēe, Go. sō; ${ }^{*} t a \bar{a}$ : Lith. tà, OCS $t a$; Lat. ha-ec, ista; Skt. káa ; OCS ona), happened to be homophonous with the stem element in a group of nouns, including $g^{w} e n \bar{a}$ 'woman,' which possessed natural female reference. ${ }^{3}$ However, since gender "classification starts with the demonstrative and only sometimes ends up in the noun" (Greenberg 1978: 80 ), the existence of female-marking ${ }^{*}-\bar{a}$ in nouns was not a sufficient reason for the feminine gender category to arise. It was only through the subsequent reanalysis of the original deictic/demonstrative in ${ }^{*}(-) \bar{a}$ as an exponent of the feminine gender because of the formal influence of nouns like $g^{w} e n \bar{a}$ and through the extant concord relationship (both anaphoric and attributive) of demonstratives to nouns that a genuine feminine gender category was ultimately established in Indo-European Proper (non-Anatolian Indo-European). That is ${ }^{*} \bar{a}$, especially in its contaminated form with the demonstrative/deictic *se/o (e.g., nom. sg. Skt. sá, Gk. hó, Go. sa), i.e. *sā, came to agree anaphorically and attributively with nouns in ${ }^{*}-\bar{a}$.

In contrast, Ledo-Lemos sees the origin of the feminine gender category in the specialization of "relational adjectives" in ${ }^{*}-(e) H_{2}-$ a suffix equivalent to ${ }^{*}-\bar{a}$ according to a less conservative view than my own of the number of laryngeal consonants in the Indo-European phonological inventory, ${ }^{4} \mathrm{~A}$ relational adjective is "an adjective derived from a noun whose role is in effect to relate that noun to a noun that it qualifies. E.g. routière in French police routière 'traffic police': lit. 'police' (police) to do with the 'road' (route)" (Matthews 1997: 315). Ledo-Lemos (2003: 123) emphasizes "the ease with which the 'relational adjectives' appear alternatively as nouns or adjectives and their great semantic mutability," i.e. the large number of functions which they tend to assume (e.g., serving as markers of abstracts and collectives). The specialization of the relational adjective suffix *-(e) $\mathrm{H}_{2}$ as "a feminizer" supposedly "had its origin in certain periphrases of motion. In these periphrases, alongside the noun for 'female' or for 'woman,' there would have been a relational adjective derived from the name of the corresponding animal or person (something similar to what occurs in the Spanish periphrasis 'hembra ovina' [noun + adjective], or in the English expression 'an ovine

\footnotetext{
3 The significance of such nouns in the emergence of the feminine gender was first pointed out by Brugmann (1897).

4 Voyles (2004) also recently supports the reconstruction of a single laryngeal for Indo-European based on evidence from Hittite.
} 
female' (2003: 124). He argues that the thematic suffix ${ }^{*}-e / o$ - may also have had its origin as a relational adjective marker, which thereby explains "the coexistence within the same [adjectival] paradigm of the thematic type and of the $\bar{a}$-stems" (2003: 128). LedoLemos sees two factors involved in the specialization of the relational adjective in (e) $\mathrm{H}_{2}$ as a "feminizer" when it occurred in periphrases with 'woman,' 'female,' or the like-economy and distinctiveness. Simply, the range of meanings assumed by the original relational adjective suffix encouraged specialization as part of the general diachronic tendency for languages to limit the range of divergence between form and function, or, as Ledo-Lemos (2003: 130) describes it, "the balance between distinctiveness and economy towards which all languages tend." Moreover, he mentions that "the appearance of the thematic type" of relational adjectives may have "prompted the suffix ${ }^{*}(e) \mathrm{H}_{2}$ to specialize as a feminine marker" (2003: 130).

In critiquing my theory of the origin of the feminine gender, Ledo-Lemos (2003: 117) emphasizes that although I "accept Brugmann's explanation for the 'feminization' process of the desinence ${ }^{*}-\bar{a}$ " because "some nouns of especially significant feminine semantics coincided by chance in having this desinence," I nevertheless "consider that the origin of gender agreement must be sought in the pronouns." He positively indicates that "the novelty of [my] ... proposal, therefore, is the hypothesis that, before the ending * $\bar{a}$ was recognized as a 'feminine' marker, there already existed a pronoun * $s \bar{a}$, which was not originally feminine" (2003: 117). In this regard, my proposal achieves typological consistency. However, he sees three problems in my formulation. First, he questions the plausibility of my explanation of the origin of the demonstrative pronoun *sa from the contamination of deictics in ${ }^{*} s e / o$ and ${ }^{*} \bar{a}$ because "the existence of a particle ${ }^{*} \bar{a}$ is ... debatable" (2003: 117). In response, it must be pointed out that the origin of the demonstrative *s $\bar{a}$ itself is, to a large extent, irrelevant to my theory of the origin of the feminine gender. There is no doubt that Indo-European possessed a demonstrative in ${ }^{*} s \bar{a}$, and my argument that it was originally used without feminine reference can be made whatever its origin was. In light of Schmid's reconstruction (1972) of an Indo-European deictic system expressing up to six degrees of spatio-temporal distance and the recognition that the natural weakening of the force of deictic elements prompts the creation of new deictic markers, the coexistence of a deictic/demonstrative in ${ }^{*} s \bar{a}$ with a variety of other forms would not be surprising. Nevertheless, I believe that Hirt (1927: 12) makes an excellent case for the reconstruction of a deictic particle in ${ }^{*} a / \bar{a}$ when he observes: " $a$ und $\bar{a}$ sind als selbständige Partikeln nicht vorhanden. Sie sind aber wohl vorauszusetzen, da $a$ in Verbindung mit andern, sonst antretenden Lauten auftritt, vgl., z.B. gr. $a i$ 'wenn,' gr. $a \hat{u}$ 'wiederum,' 1. $a u-t$ 'oder,' got. $a u-k$, d. auch 'noch dazu,' 1. $a d$ 'zu,' 1. $a b$, gr. an, got. an usw. ...Ein Pronomen $\bar{a}$ findet sich im Indischen I. D. Abl. Du. ā-bhyám, I. Pl. F. ā-bhís, D. ābhyás, G. āsám, L. $\bar{a} s u ́$, das doch wohl auf idg. $\bar{a}$ zurückgeht." ${ }^{5}$ Because the markers of adver-

\footnotetext{
5 Dunkel (1992: 156-157) emphasizes that Indo-European deictic particles were subject to ablaut variation.
} 
bial cases frequently derive from the grammaticalization of deictic particles, I have proposed that the deictic particle ${ }^{*} a / \bar{a}$ is attested in the Old Hittite directive suffix $-a$ (cf. nu wetena paizzi 'and he goes to the water') (Shields 2004); in "fossilized" locative forms like Gk. háma 'at the same time, at once,' pará 'near, beside,' and, in contamination with the particle ${ }^{*} i$, in locative forms like khamai 'on the ground' (Sihler 1995: 348), parai 'near, beside' (Beekes 1985: 125); and more generally in the Homeric Greek athematic infinitive suffix in -ai (cf. -sai, -sthai), which reflects the contamination of deictics in ${ }^{*} a$ and ${ }^{*} i$ as a dative-locative desinence (Shields 2005). ${ }^{6}$ To me, the reconstruction of a deictic in ${ }^{*} a / \bar{a}$ has ample support.

Secondly, Ledo-Lemos (2003: 118) maintains that my theory "does not resolve the more substantial problem of how agreement originated." Although it "may explain how agreement arose in the pronoun," it "leaves us without any explanation of how it went from there to the adjectives," for "in a language in which agreement is limited to the pronoun, we would expect that the assignment criteria be strictly semantic" (2003: 118). In response, I would submit that since the demonstrative functioned both anaphorically and attributively, the demonstrative, in the latter function, was fundamentally adjectival in nature. Because a classic "mixed" gender concord system involving both formal and semantic aspects was already in place for Indo-European nouns and their attributive, i.e. adjectival, words prior to the emergence of the feminine, the newly created feminine of attributive pronouns was analogically extended to genuine adjectives. Such an integrative development would have been natural indeed.

Finally, Ledo-Lemos (2003: 118) asserts that my theory does not explain the important matter of why feminine gender agreement was extended "to the thematic adjectives, but not to the athematic type." He believes that his derivation of the thematic suffix ${ }^{*}-e / o^{-}$and the feminine suffix ${ }^{*}-\bar{a}$ - from relational adjective markers accounts for their integration into a single paradigm. Despite his skepticism, my theory, when viewed in the context of traditional opinions about the origin of thematic declension, yields a rather simple explanation. Although a variety of sources of the thematic vowel have been postulated (cf. Brosman 1998 and Shields 2002), ${ }^{7}$ there is

\footnotetext{
6 "Although the latter [Greek forms] have provoked considerable dissention about the origin and antiquity of their case suffix (Sihler 1995: 251), I believe that in light of the gradual and largely dialectal emergence of the adverbial cases through the grammaticalizaton of deictic particles and in light of the polymorphic variation inherent in this development, the appearance of adverbial case forms in *-ai would not have been unexpected. Original dative-locatives in *ai have been rejected on the basis of the fossilized Greek datives in *-ei (e.g., Diwei-philos 'dear to Zeus'; cf. Sihler 1995: 251), but the existence of the latter does not preclude the existence of the former. Indeed, the issue here is not which of the two suffixes represents the original Indo-European dative singular affix, although this is the usual form of the debate (cf. Burrow 1973: 233), but simply whether it is reasonable to ascribe both to the early history of Greek and perhaps other dialects" (Shields 2004: 1819). See Shields (2005) for specific arguments in support of a dative-locative marker ${ }^{*}$-ai within the context of these general observations.

${ }^{7}$ In Shields (2002), I propose a verbal origin for the stem-suffix of thematic nominal declension.
} 
general agreement that the $o$-stems are a late development, demonstrated especially by their paucity in Hittite (cf. Lehmann 1993: 247 and Brosman 1998: 65). Therefore, all Indo-European adjectives were originally athematic, occurring especially as members of the consonant-stem class (Meier-Brügger 2003: 199), and these athematic forms began to undergo systematic affixation by both ${ }^{*}-e / o$ - and ${ }^{*} \bar{a}$ - in the early period of Indo-European Proper. Since the same original athematic adjective was subject to analogical extension by newly emergent ${ }^{*}-\bar{a}$ - when in concord with semantically and/or formally feminine nouns, and by newly emergent ${ }^{*}-e / o$ - when in concord with other nouns, that adjective was naturally analyzed as having two forms. The regularity of these analogical processes resulted in the fact that "the $o$-stems are ... the most frequently found" class of adjectives (Beekes 1995: 196), although, as one would expect, these analogical processes left behind "residue" in the form of attested athematic adjectives. However, it is incorrect to say that the feminine gender was not extended to athematic adjectives which constitute such "residue" since many-but not allattest ${ }^{*} \bar{a}^{-}$"after the adjectival suffix and only with the $u$-stems" or attest the suffix *$y \bar{a}$-, even though the key point to be made here is that these adjectives are unlike the $o$-stems, which "have the ... suffix for the feminine ... in place of the - $o$-, not following it" (Beekes 1995: 197). Once again, this development is simply the result of the fact that the vast majority of consonant-stem adjectives adopted the late-emerging suffixes $*_{-e / o-}$ and ${ }^{*}-\bar{a}$ - as part of two simultaneously occurring analogical processes and, in addition, the fact, supported by "all explanations offered for the $\bar{i} / y \bar{a}$ - stems," that the latter "originated in some manner under the influence of previously existing $\bar{a}$ stems" (Brosman 2002: 9). In other words, "there does appear to be agreement that the $\bar{a}$ - stems arose prior to the $\bar{i} / y \bar{a}$ - stems" (Brosman 2002: 9), and therefore the existence of the latter postdates the establishment of a distinctively feminine gender as the athematic "residue" tended to be given a feminine form through subsequent analogical reformulation. ${ }^{8}$

I want to conclude my remarks by pointing out that the theory of Ledo-Lemos engenders certain questions which call into doubt its explanatory power. In the first place, his proposed reanalysis of relational adjectives in *- $\bar{a}$ - as possessing a "feminizer" suffix is unmotivated analogically. According to the principles of economy and distinctiveness which he cites as causative factors, any number of reanalyses would have been possible since relational adjectives in ${ }^{*}-\bar{a}-$ would have been involved in periphrases with nouns of a wide variety of semantic content. Even if one accepts his argument that periphrases involving relational adjectives in ${ }^{*}-\bar{a}$ - and nouns frequently occurred in Indo-European, just why these relational adjectives became feminine is unclear. Similarly, the existence of functionally equivalent (doublet) relational adjectives in ${ }^{*}-e / o$ - and ${ }^{*}-\bar{a}$ - would not have automatically resulted in their incorporation into the same paradigm. It would seem quite possible that two different paradigms could have been created, as was the case in Indo-European nouns. Thus, the

\footnotetext{
${ }^{8}$ See, for example, Shields (1982: 77-81) in this regard.
} 
theory of Ledo-Lemos suffers from the same problem which he erroneously ascribes to my theory-the failure to explain why feminine gender agreement "went ... to the thematic adjectives, but not to the athematic type" (2003: 118).

The debate about the origin of the Indo-European feminine gender will most certainly continue for years to come. And such debate will most certainly enrich the field of Indo-European studies since it prompts the development of new ideas and the improvement of existing ones. I find the theory of Ledo-Lemos to be useful in leading the debate about the origin of the feminine gender in a new, potentially productive direction, although I have concerns about the specifics of its current state of formulation. Of equal significance, I find his theory important in forcing me to refine aspects of my own scholarship regarding this fascinating issue.

\section{References}

BeEkes, Robert S. P. (1985) The Origins of the Indo-European Nominal Inflection. Innsbruck:

Institut für Sprachwissenschaft der Universität Innsbruck.

Beekes, Robert S. P. (1995) Comparative Indo-European Linguistics: An Introduction.

Amsterdam: Benjamins.

Brosman, Paul (1998) "On the Origin of PIE o-Stems." Folia Linguistica Historica 19, 65-78.

Brosman, Paul (2002) "Evidence in Support of Proto-Indo-Hittite." Folia Linguistica

Historica 23, 1-21.

Brugmann, Karl (1897) The Nature and Origin of the Noun Genders in Indo-European. Trans. E.

Robbins. New York: Schribner's.

Burrow, Thomas (1973) The Sanskrit Language. Rev. ed. London: Faber \& Faber.

Corbett, Greville (1991) Gender. Cambridge: Cambridge University Press.

Dunkel, George E. (1992) "Die Grammatik der Partikeln." In: R. Beekes et al. (eds),

Rekonstruktion und relative Chronologie. Innsbruck: Institut für Sprachwissenschaft der

Universität Innsbruck, 153-177.

Euler, Wolfram (1991) "Die Frage nach der Entstehung der indogermanischen Genera im

Lichte der Relativen Chronologie." Indogermanische Forschungen 96, 36-45.

GreenberG, Joseph 1978: "How Does a Language Acquire Gender Markers?” In: J. Greenberg

et al. (eds), Universals of Human Language. III. Stanford: Stanford University Press. 47-82.

HIRT, Hermann (1927) Indogermanische Grammatik. III. Heidelberg: Winter.

Ledo-lemos, Francisco José (2003) Femininum Genus: A Study of the Origins of the Indo-

European Feminine Grammatical Gender. Munich: LINCOM Europa.

Lehmann, Winfred P. (1993) Theoretical Bases of Indo-European Linguistics. London/New York:

Routledge.

Matasović, Ranko (2004) Gender in Indo-European. Heidelberg: Winter.

Matthews, P. H. (1997) The Concise Oxford Dictionary of Linguistics. Oxford: Oxford University Press.

MeIER-BrügGer, Michael (2003) Indo-European Linguistics. Berlin: De Gruyter.

Melchert, Craig H. (1994) “The Feminine Gender in Anatolian.” In: G. Dunkel et al. (eds)

Früh-, Mittel-, Spätindogermanisch. Wiesbaden: Harrassowitz, 231-234. 
Schmid, Wolfgang P. (1972) Die pragmatische Komponente in der Grammatik. Mainz: Akademie der Wissenschaften und der Literatur.

SchwInk, Frederick W. (2004) The Third Gender: Studies in the Origin and History of Germanic Grammatical Gender. Heidelberg: Winter.

SHIELDS, Kenneth (1977) "Some New Observations Concerning the Origin of the IndoEuropean Feminine Gender." Zeitschrift für vergleichende Sprachforschung 91, 56-71.

Shields, Kenneth (1979) "A Theory of Gender Change." Glossa 13, 27-38.

SHIELDS, Kenneth (1982) Indo-European Noun Inflection: A Developmental History. University Park: Penn State Press.

SHIELDS, Kenneth (1995) "On the Origin of the Indo-European Feminine Gender." Indogermanische Forschungen 100, 101-108.

SHIELDS, Kenneth (2002) "Speculations about the Origin of the Indo-European o-Stems." Folia Linguistica Historica 23, 23-30.

SHIELDS, Kenneth (2004) "On the Origin of the Old Hittite Directive." Historische Sprachforschung 117, 15-21.

SHields, Kenneth (2005) "Some Comments about the Indo-European Dative Singular." Studia Etymologica Cracoviensia 10, 157-163.

Sihler, Andrew L. (1995) New Comparative Grammar of Greek and Latin. New York: Oxford University Press.

Stempel, Reinhard (1994) " $i$-Genitiv, $i$-Motion und Femininum: Versuch einer Synthese.” In: R. Bielmeier/R. Stempel (eds), Studia Indogermanica et Caucasica: Festschrift für K. H. Schmidt zum 65 Geburtstag. Berlin: De Gruyter, 197-210.

Tichy, Eva (1993) "Kollektiva, Genus femininum und relativ Chronologie im Indogermanischen." Historische Sprachforschung 106, 1-19.

Voyles, Joseph (2004) "A Reassessment of Hittite Historical Phonology." Interdisciplinary Journal of Germanic Linguistics and Semiotic Analysis 9, 145-163.

ZeILFelder, Susanne (2001) Archaismus und Ausgliederung. Studien zur sprachlichen Stellung des Hethitischen. Heidelberg: Winter. 


\section{Abstract \\ MORE ON THE ORIGIN OF THE INDO-EUROPEAN FEMININE GENDER: \\ A REPLY TO LEDO-LEMOS}

This brief paper has two related purposes. First, it represents a response to Ledo-Lemos' criticisms (2003) of the theory of the origin of the Indo-European feminine gender presented in Shields (1995 and elsewhere)-a theory based on the established typological principle that demonstratives (in this case, a demonstrative in ${ }^{*} \bar{a}$ ) are key in the emergence of gender systems because of their dual role as anaphora and attributive modifiers. Second, this paper includes critical commentary about Ledo-Lemos' own hypothesis regarding the origin of this Indo-European grammatical category, grounded in the specialization of "relational adjectives." Objections to the latter involve his reliance on unmotivated analogical reanalysis and paradigmatic specialization.

\section{Povzetek \\ ŠE NEKAJ O IZVORU INDOEVROPSKEGA ŽENSKEGA SPOLA: ODGOVOR LEDO-LEMOSU}

Pričujoči članek ima dva med sabo povezana namena. Najprej je odgovor na Ledo-Lemosovo kritiko (2003) teorije izvora indoevropskega ženskega spola, predstavljene v Shields (1995 in drugod). Ta teorija izhaja iz sprejetega tipološkega načela, da so kazalni zaimki ( $\mathrm{v}$ tem primeru kazalni zaimek z *ā) zaradi svoje dvojne vloge kot anafora in kot prilastkovo določilo ključni za nastanek sistemov spola. Obenem članek prinaša kritičen komentar LedoLemosove lastne hipoteze o izvoru te indoevropske slovnične kategorije, ki naj bi temeljil v specializaciji »relacionalnih pridevnikov«. Ugovori Ledo-Lemosovi teoriji zadevajo njegovo zanašanje na neutemeljene analoške reanalize in paradigmatske specializacije. 